\title{
PCR based detection of gyrB2 gene from Pseudomonas sp. affected human clinical isolates
}

\author{
*Md. Javed Foysal, Gokul Chandra Biswas, Md. Jahir Raihan \\ Department of Genetic Engineering and Biotechnology, Shahjalal University of Science and Technology, Sylhet-3114, Bangladesh
}

\begin{abstract}
Detection of virulence gene is a key component in determining the pathogenicity of any isolates because these genes act multi-functionally and multi-factorially. Gyrase specific gene primer in combination of PCR technology allows precise detection of DNA gyrase subunit B2 gene (gyrB2) from different virulent microorganisms. In the present study, forward and reverse primers with a length of 20bp for both were used for detection of gyrB2 genes in clinical isolates of Pseudomonas sp. collected from patients suffering from urinary tract infection (UTI). A total of 12 isolates of Pseudomonas sp. viz., Ps1, Ps2, Ps3, Ps4, Ps5, Ps6, Ps7, Ps8, Ps9, Ps10, Ps11 and Ps12 were used in present study in which gyrB2 gene amplified in all 12 isolates and gave the expected 1130bp PCR product after visualization under gel documentation system in $1.2 \%$ agarose gel. This PCR was outstanding in the detection of gyrB2 gene in urinary tract infected patients caused by Pseudomonas sp. species.
\end{abstract}

Key Words: Pseudomonas sp., virulence gene, gyrB2, PCR detection, visualization.

\section{INTRODUCTION}

Molecular techniques have been resolved in recent years for detection of pathogen and their virulent genes proven promising in disease diagnosis and prophylaxis. Among them Polymerase Chain Reaction (PCR) is the most significant one in last couple of years. Pseudomonas species are Gram negative, catalase positive, oxidase positive, rod shaped, non-motile bacteria that are found in the environment (Nathan et al., 2011) and also in the human clinical samples (Oberhofer, 1980). Urinary Tract Infection (UTI) is the commonest infection among patients in intensive care facilities across the world ant it ranks worst among patient morbidity and mortality cases in hospital acquired infections (Mittal et al., 2009). Saber et al. (2010) described that the UTI infection in Bangladesh caused by Pseudomonas species are due to the virulence factors expressed by the organism. Bajaj et al. (1999) reported that Pseudomonas species caused urinary

\footnotetext{
*Corresponding Author:

Md. Javed Foysal

Department of Genetic Engineering and Biotechnology

Shahjalal University of Science and Technology

Sylhet-3114, Bangladesh.

E-mail: faisalron04@yahoo.com

Contact No.: +88 01717389379
}

tract infection $(9.64 \%)$ in maximum number of cases followed by Staphylococcus aureus (6.93\%). Several genes responsible for virulence properties of Pseudomonas species but DNA gyrase subunit B2 gene (gyrB2) is the principle one has been reported by many researchers. DNA gyrase is a prokaryotic type II topoisomerase which cut both strands of the DNA helix simultaneously in order to manage DNA tangles and supercoils and a major target of quinolone antibacterials (Nitiss, JL., 2009). Nitiss also reported that the majority of mutations conferring resistance to quinolones arise within the quinolone resistance-determining region of GyrA close to the active site $\left(\mathrm{Tyr}^{122}\right)$ where DNA is bound and cleaved. However, some quinolone resistance mutations are known to exist in GyrB. Campbell et al. (1995) detect Pseudomonas sp. by PCR in infant's through16s rRNA sequencing Dauga (2002) amplified gyrB gene and performed molecular phylogenetic analysis in enterobacteriaceae.

\section{MATERIALS AND METHODS}

Collection of bacterial isolates

Pseudomonas sp. bacterial isolates were collected from three different medical colleges and hospitals of Sylhet district, Bangladesh viz. M. A. G. Osmani 
Table 1. Pseudomonas sp. solates with their isolation history.

\begin{tabular}{llc}
\hline Isolates & Collected from & Type of patient \\
\hline Ps1 & M. A. G. Osmani Medical College and Hospital, Sylhet, Bangladesh & UTI \\
Ps2 & M. A. G. Osmani Medical College and Hospital, Sylhet, Bangladesh & UTI \\
Ps3 & Ragib-Rabeya Medical College and Hospital, Sylhet, Bangladesh & UTI \\
Ps4 & M. A. G. Osmani Medical College and Hospital, Sylhet, Bangladesh & UTI \\
Ps5 & M. A. G. Osmani Medical College and Hospital, Sylhet, Bangladesh & UTI \\
Ps6 & M. A. G. Osmani Medical College and Hospital, Sylhet, Bangladesh & UTI \\
Ps7 & Ibn Sina Hospital, Sylhet, Bangladesh & UTI \\
Ps8 & M. A. G. Osmani Medical College and Hospital, Sylhet, Bangladesh & UTI \\
Ps9 & M. A. G. Osmani Medical College and Hospital, Sylhet, Bangladesh & UTI \\
Ps10 & M. A. G. Osmani Medical College and Hospital, Sylhet, Bangladesh & UTI \\
Ps11 & Ibn Sina Hospital, Sylhet, Bangladesh & UTI \\
Ps12 & Ragib-Rabeya Medical College and Hospital, Sylhet, Bangladesh & UTI \\
\hline
\end{tabular}

Medical College Hospital, Ibn Sina Hospital and Ragib-Rabeya Medical College and Hospital, Bangladesh (Table 1). Isolates were collected from patients suffering from urinary tract infection (UTI).

\section{Culture condition}

The bacterial isolates were streaked in nutrient agar plates from previous plate and incubate in $37^{\circ} \mathrm{C}$ for overnight for appropriate colony formation. After the incubation the single colony of each plate was selected for re-isolation to a pure culture in nutrient agar plate.

\section{DNA extraction}

A total of 12 bacterial isolates were inoculated in nutrient broth culture and incubated overnight at $37^{\circ} \mathrm{C}$ and $120 \mathrm{rpm}$ in a shaker incubator. The bacterial genomic DNA was extracted by using commercial DNA extraction kit (Bio Basic Inc., 160 Torbay Road, Markham Ontario, Canada) and extracted DNA was preserved at $-20^{\circ} \mathrm{C}$ in an ultra freezer.

\section{PCR reaction mixture set up}

The PCR was performed in $25 \mu$ reaction mixtures containing DNA template (genomic DNA of bacteria) of $1.2 \mu \mathrm{l}, 1 \mu \mathrm{l}$ of $25 \mathrm{mM} \mathrm{MgCl} 2,5 \mu \mathrm{l}$ of $5 \mathrm{x}$ colorless reaction buffer, $0.5 \mu$ l concentration of each deoxynucleotide triphosphate (dNTP), 1.2 $\mu$ l of each forward primer and reverse primer (Table 2) and
$0.15 \mu$ l DNA polymerase along with its amplification buffer.The amplifications were carried out in a MultiGene gradient thermal cycler (Labnet International Inc. USA).

\section{Amplification condition}

PCR reaction was optimized with the following parameters: an initial denaturation step of $94^{\circ} \mathrm{C}$ for 4 min; a denaturation step of $94^{\circ} \mathrm{C}$ for $1 \mathrm{~min}$, annealing at $62^{\circ} \mathrm{C}$ for $1 \mathrm{~min}$, and extension at $72^{\circ} \mathrm{C}$ for $90 \mathrm{~s}$; and a final extension step of $72{ }^{\circ} \mathrm{C}$ for $10 \mathrm{~min} .35$ serial cycles of reaction was performed.

\section{RESULTS AND DISCUSSION}

Amplified PCR products were detected by agarose gel electrophoresis of each of amplification mixture in $1.2 \%$ agarose gels in $0.5 \%$ Tris-borate-EDTA buffer. Gel was stained with ethidium bromide solution $(10 \mathrm{mg} / \mathrm{ml})$ for 20 minutes followed by destaining in distill water for 10 minutes. The position of each band on gel then visualized and documented in a gel documentation system. GyrB2 gene has been amplified in all isolates of Pseudomonas sp., viz., Ps1, Ps2, Ps3, Ps4, Ps5, Ps6, Ps7, Ps8, Ps9, Ps10, Ps11 and Ps12. The sizes of the amplification products obtained by the PCR were identical to those predicted from the target gyrB2 primers (Figure 1).

Table 2. Primer used for present study.

\begin{tabular}{llll}
\hline Primer & Sequence $\left(\mathbf{5}^{\prime}\right.$ to $\mathbf{3}^{\prime}$ ) & PCR product length & Pathogen \\
\hline GyrB2-F & TCCGGCGGTCTGCACGGCGT & 1130bp & Pseudomonas sp. \\
GyrB2-R & TTGTCCGGGTTGTACTCGTC & & \\
\hline
\end{tabular}




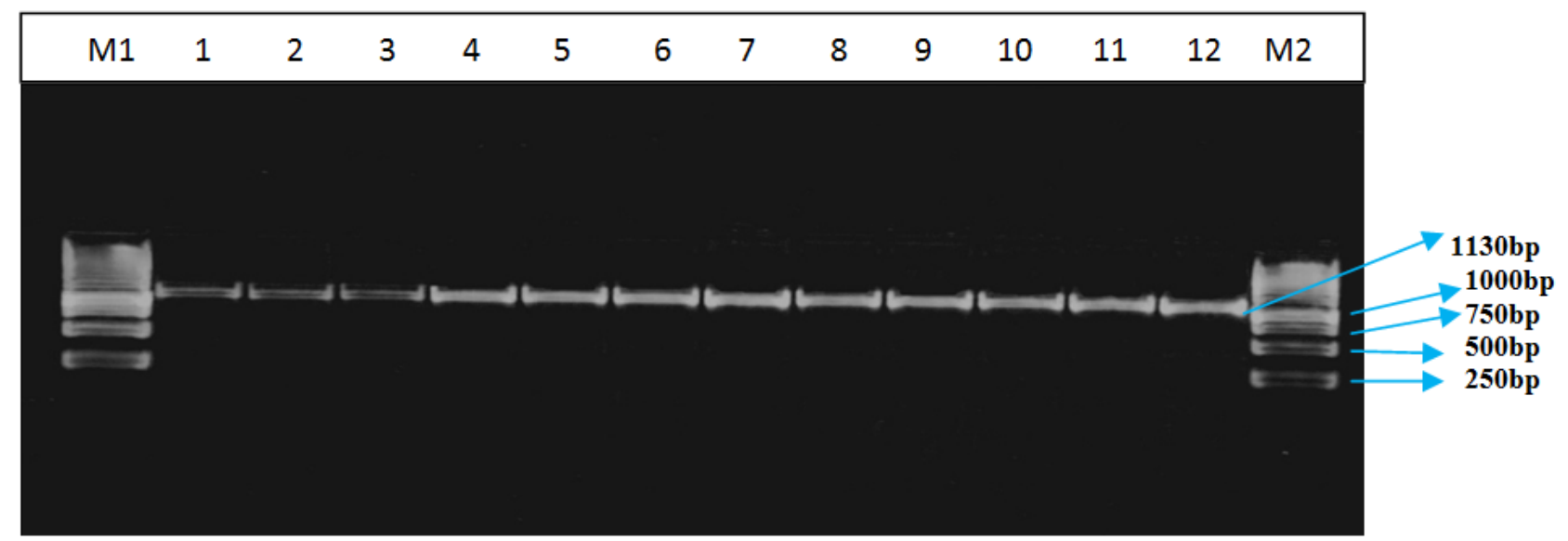

Figure 1: PCR amplification of gyrB2 gene in Pseudomonas sp. with expected product length of 1130bp in $1.2 \%$ agarose gel. $\mathrm{M} 1$ and $\mathrm{M} 2=1 \mathrm{~kb}$ DNA ladder $1-12=$ Pseudomonas sp. isolates

1=Ps1, 2=Ps2, 3=Ps3, 4=Ps4, 5=Ps5, 6=Ps6, 7=Ps7, 8=Ps8, 9=Ps9, 10=Ps10, 11=Ps11 and 12=Ps12.

Pseudomonas sp. has been reported as a common pathogen for human associated with pneumonia and other diseases. Turner et al. (2009) described that the pathogenicity of Pseudomonas aeruginosa depend on the expression of a diverse set of genes. Bradbury (2010) determined virulence factors of Pseudomonas aeruginosa by PCR and find out virulent genes that contribute pathogenicity of Pseudomonas $s p$.. The gyrB gene is a single-copy gene, present in all bacteria which encode the ATPase domain of DNA gyrase, an enzyme essential for DNA replication (Huang, 1996). Earlier studies reported that gyrase subunit B2 gene contribute the major virulence properties of many bacterial species and has been used as a molecular tool for identification of bacterial species (Coenye and LiPuma, 2002) and phylogenetic analysis (Yamamoto and Harayamapcr, 1995; Shen et al., 2006). Podschun and Ullmann (1998) reported the contribution of gyrB2 gene in progression of enterobactericeae associated disease. In present study all collected (12) isolates were positive for gyrB2 gene revealing the distribution and virulence properties of these gene in Pseudomonas species and confirms the detection of gyrB2 gene product of $1130 \mathrm{bp}$ using PCR as a taxonomic marker.

\section{ACKNOWLEDGEMENT}

The present study was conducted under a research project titled "Molecular Detection of Bacterial and Fungal Diseases of Carp and Fish and Herbal
Treatment for Remedy of the Diseases" funded by United States Department of Agriculture (USDA).

\section{REFERENCES}

Bajaj, J. K., Karyakarte, R. P., Kulkarni, J. D., Deshmukh, A. B. (1999). Changing aetiology of urinary tract infections and emergence of drug resistance as a major problem. Journal of Common Diseases. 31(3): 181-184. PMID:10916615

Bradbury, R.S., Roddam, L. F., Merritt, A., Reid, D. W., Champion, A. C. (2010). Virulence gene distribution in clinical, nosocomial and environmental isolates of Pseudomonas aeruginosa. Journal of Medical Microbiology. 59: 881-890. [DOI]

Campbell, P.W., Phillips, J. A., Heidecker, G. J., Krishnamani, M. R., Zahorchak, R., Stull, T. L. (1995). Detection of Pseudomonas (Burkholderia) cepacia using PCR. Pediatric Pulmonol. 20(1): 44-49. PMID:7478781

Coenye, T., LiPuma, J. J. (2002). Use of the gyrB gene for the identification of Pandoraea species. FEMS Microbiology Letters. 208: 15-19. PMID:11934487

Dauga, C. (2002). Evolution of the gyrB gene and the molecular phylogeny of Enterobacteriaceae: a model molecule for molecular systematic studies. International Journal of Systematic and Evolutionary Microbiology. 52 531-547. [DOI]

Foysal, M.J., Rahman M. M., Alam, M. (2011). Antibiotic Sensitivity and in vitro antimicrobial activity of plant extracts to Pseudomonas fluorescens isolates collected from diseased fish. International Journal of Natural Science. 1(4): 82-88. [DOI]

Huang, W. M. (1996). Bacterial diversity based on type II DNA topoisomerase genes. Annu Rev Genet. 30: 79-107. PMID:8982450 
Podschun, R., Ullmann, U. (1998). Klebsiella spp. as Nosocomial Pathogens: Epidemiology, Taxonomy, Typing Methods, and Pathogenicity Factors. Clinical Microbiology Reviews. 11: 589-603. PMID:9767057

Mittal, R., Aggarwal, S., Sharma, S., Chhibber, S., Kusum Harjai, K. (2009). Urinary tract infections caused by Pseudomonas aeruginosa: A minireview. Journal of Infection and Public Health. 2: 101-111. [DOI]

Nathan, P., Rathinam, X., Kasi, M., Rahman, Z. A., Subramaniam, S. (2011). A pilot study on the isolation and biochemical characterization of Pseudomonas from chemical intensive rice ecosystem. African Journal of Biotechnology. 10(59): 12653-12656. [DOI]

Nitiss, J.L. (2009). DNA Topoisomerase II and Its Growing Repertoire of Biological Functions. Nature publishing group. 16: 1-6. [DOI]

Oberhofer., T.R. (1980). Cultural and Biochemical Characteristics of Clinical Isolates of Unusual Colistin-Resistant Pseudomonads. Journal of Clinical Microbiology. 12(2): 156160. PMID:7229004

Rahman, M. M., Ferdowsy, H., Kashem, M. A., Foysal, M. J. (2010). Tail and fin rot disease of carp and climbing perch in Bangladesh. Journal of Biological Sciences. 10(8): 800804. [DOI]
Saber, M.H., Lovely Barai, L., Haq J.A., Jilan, S. A., Begum, M. J. (2010). The Pattern of Organism Causing Urinary Tract Infection in Diabetic and Non Diabetic Patients in Bangladesh. Bangladesh Journal of Medical Microbiology. 4(1): 68. [DOI]

Sharmin, R., Hossain M. N., Rahman, M. M., Foysal, M. J., Miah, F. M. (2012). In-vitro antibacterial activity of some aqueous herbal extracts against multidrug resistant Klebsiella spp. Isolated from human clinical sample, International Current Pharmaceutical Journal 1(6): 133-137. [DOI]

Shen, F.T., Lu, H.L., Lin, L.J., Wei-Shuo Huang, S. W., A.B. Arun, A. B. (2006). Phylogenetic analysis of members of the metabolically diverse genus Gordonia based on proteins encoding the gyrB gene. Res. Microbiol. 157: 367-375. PMID:16310344.

Turner, K. H., Vallet-Gely, I., Dove, L. S. (2009). Epigenetic Control of Virulence Gene Expression in Pseudomonas aeruginosa by a LysR-Type Transcription Regulator. PLoS Genet 5(12): e1000779. [DOI]

Yamamoto, S., Harayamapcr, S. (1995). PCR amplification and direct sequencing of gyrB genes with universal primers and their application to the detection and taxonomic analysis of Pseudomonas putida strains. Applied and Environmental Microbiology. 61(3): 1104-1109. PMid:7793912 PMCid:167365 